
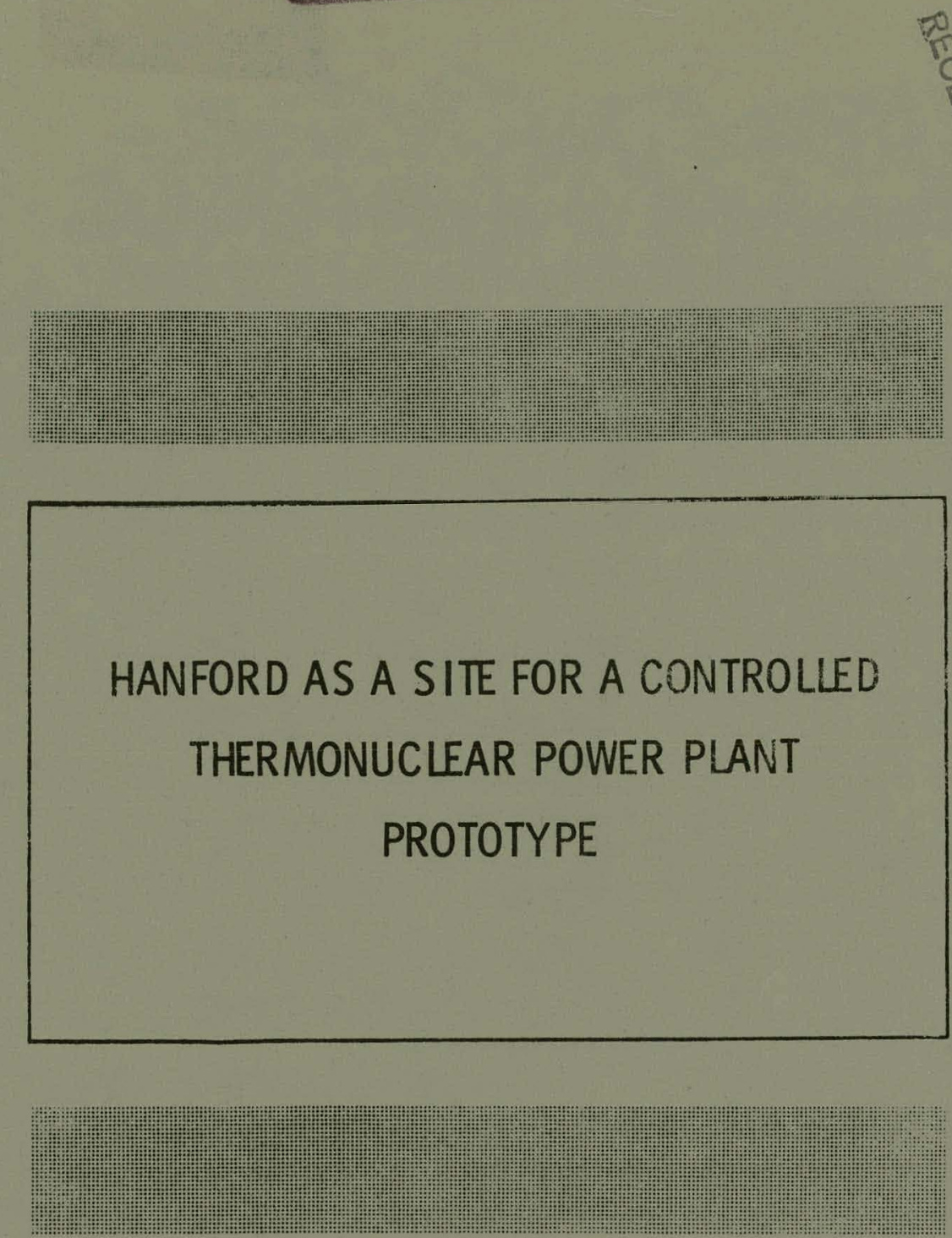

PREPARED FOR

\title{
THE UNITED STATES ATOMIC ENERGY COMMISSION
}

\section{UNDER CONTRACT AT(45-1)-1930}

\section{OFFICTALUSEONE}

\section{BATTELLE-NORTHWEST}

PACIFIC NORTHWEST LABORATORIES DIVISION BATTELLE MEMORIAL INSTITUTE

P. O. BOX 999, RICHLAND, WASHINGTON 99352 


\section{DISCLAIMER}

This report was prepared as an account of work sponsored by an agency of the United States Government. Neither the United States Government nor any agency Thereof, nor any of their employees, makes any warranty, express or implied, or assumes any legal liability or responsibility for the accuracy, completeness, or usefulness of any information, apparatus, product, or process disclosed, or represents that its use would not infringe privately owned rights. Reference herein to any specific commercial product, process, or service by trade name, trademark, manufacturer, or otherwise does not necessarily constitute or imply its endorsement, recommendation, or favoring by the United States Government or any agency thereof. The views and opinions of authors expressed herein do not necessarily state or reflect those of the United States Government or any agency thereof. 


\section{DISCLAIMER}

Portions of this document may be illegible in electronic image products. Images are produced from the best available original document. 


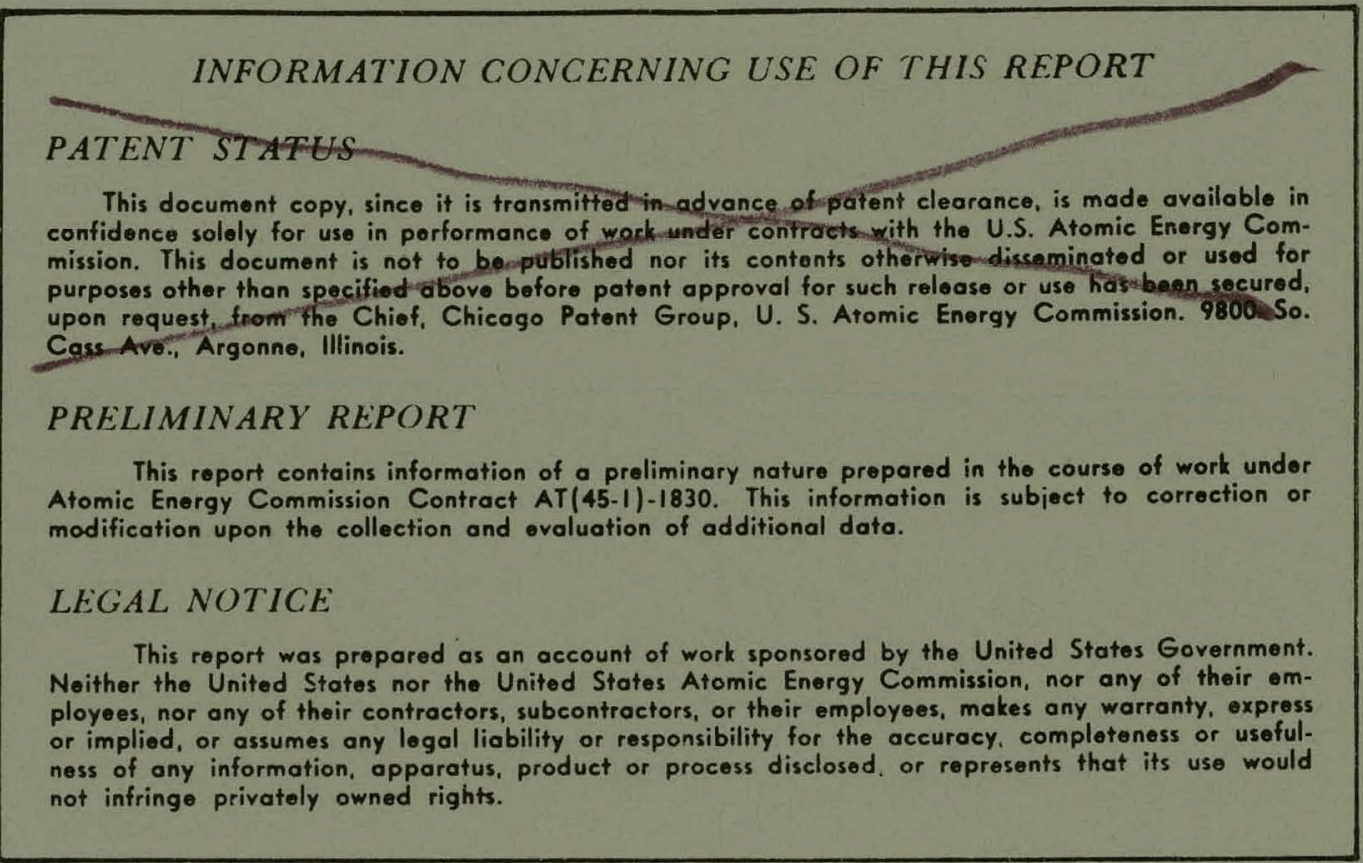

PACIFIC NORTHWEST LABORATORY

operated by

\section{BATTELLE MEMORIAL INSTITUTE}

for the

U. S. ATOMIC ENERGY COMMISSION

Under Contract AT(45-1) 1830 
Reactor Physics Denartment Physics and Engineering Division

This report was prepared as an account of work sponsored by the United States Government. Neither the United States nor the United States Atomic Energy Commission, nor any of their employees, nor any of their contractors, subcontractors, or their employees, makes any warranty, express or implied, or assumes any legal liability or responsibility for the accuracy, completeness or usefulness of any information, apparatus, product or process disclosed, or represents that its use would not infringe privately owned rights.

December 1970

This report is intended primarily for internal use by the sponsoring organization and Battelle-Northwest.

BATTELLE MEMIORIAL INSTITUTTE

PACIFIC NORTHWEST LABORATORIES

RICHLAND, WASHINGTON $99.35 ?$ 
HANFORD AS A SITE FOR A

CONTROLLED THERMONUCLEAR

POWER PLANT PROTOTYPE

\section{INTRODUCTION}

Recent advances in the field of controlled thermonuclear fusion plasma research indicate that the next gencration of research machines may demonstrate controlled thermonuclear fusion. Briefly, current laboratory devices have, within the past two years, achieved a combination of confinement time, plasma density, and plasma temperature which is several orders of magnitude higher than the level which researchers had once postulated was a theoretical limitation. In addition, this recent breakthrough puts scientists within two orders of magnitude of a sustained reaction.

Fusion cuncepts operate on one or more of the following reactions:

$$
\begin{aligned}
& H^{H^{2}}+{ }_{1} H^{3} \rightarrow{ }_{0}{ }^{7}+{ }_{2} \mathrm{He}^{4} \\
& H^{2}+{ }_{1} H^{2} \rightarrow{ }_{1} H^{3}+{ }_{1} H^{7} \\
& H^{2}+{ }_{1} H^{2} \rightarrow{ }_{2} \mathrm{He}^{3}+{ }_{0} n^{1} \\
& H^{2}+{ }_{2} \mathrm{He}^{3} \rightarrow{ }_{2} \mathrm{He}^{4}+{ }_{1} H^{1}
\end{aligned}
$$

The requirements in temperature are sufficiently lower for the $\left({ }_{1} \mathrm{H}^{2}, \mathrm{H}^{3} \mathrm{H}^{3}\right.$ reaction that one could expect initial success with this reaction.

Certain basic characteristics of a Controlled Thermonuclear Power Plant (CTPP) can be envisioned. Larqe super-conducting magnets will be required for nlasma confinoment. There $v i 11$ he significant quantities of tritium to be separated and confined. The power plant size will be in the thousands of megavatt range. It will have a liquid melal or gas coolant onerating at ulono"C witil perhaps a liquid metal topping turbine and a steam turbine. 
Nthough it will be some time before a detailed design of a fusion reactor will be available, the general design criteria for a fusion reactor can be discussed. Experimental efforts to date have included work on toroidal and mirror (i.e., long straight tube with magnetic mirrors at the ends) maclines. These current experimental machines are at a stage of development relative to actual power plants similar to what $\mathrm{CP}-1$ was to the LWR. The center of the plastila region would consist of stripped deuterium and tritium atoms heated to millions of degrees and held in a vacuum. The plasma would be surrounded by a vacuum wall of niobium or molybdenum. This wall would be surrounded by a lioderator/coolant region that could be riade of graphite and liquid lithium. The lithium could act as a coolant and breeding ground for tritium and is followed by a combined heat shield and radiation shield. Surrounding the shield region, powerful superconducting magnets provide the magnetic bottle required to confine the plasila.

If contrnlled fusion is about to be a reality, one can make some guesses as to how the program might progress based on the previously successful fission reactor program. The results of an initial reviev are summarized in figure 1 . This timetable anticipates a prototype :onstruction start in 1982. Initial site preparationa might. begin in 1930. Therefore, a site would have to be selected by the mid. or late-1970s. This report was develcped on the basis of such a projected need.

There are two safety considerations of importance connected with a CTPP. They are:

- Tritium leakage to the environment.

- Energy release from liquid metal coolant. The stored energy within the fusion :..re itself is so small that any sort of destructive run-away acciddnt cannot be envisioned. Moreover, all devialions from normal operating conditions tend to depress the reaction. 


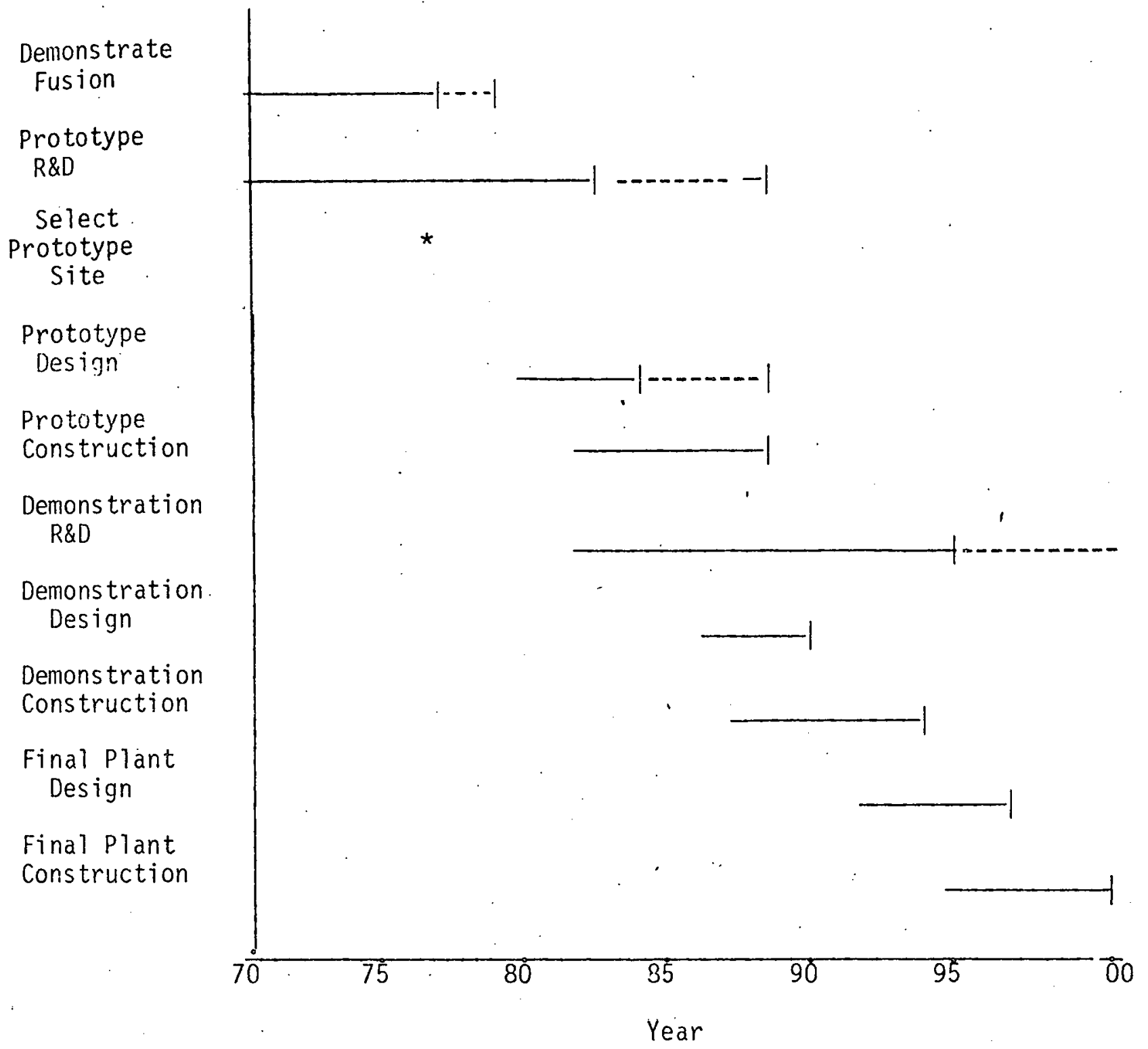

Figure 1

Simplified Time Table' for Controlled Fusion Development 
Tritium release from a CTPP is likely to be significant. Current estimates show that the leakage can easily be within an order of magnitude of the federal regulations.

The potential energy release from a CTPP cooled by liquid metals is theoretically very large. Putting aside for the moment the difficulties in acilieving these high theoretical energy releases in an accident situation, it can be readily shown for a 5000 Mve plant cooled by liquid lithium that the potential energy release is of the order of $3 \times 10^{6} \mathrm{HW}-\mathrm{sec}$ (700 tons TNT). Such an energy relcase could involve the subsequent release of significant radioactive material.

The imnlications of the above considerations on the siting of a prototypic CTPP are significant and are reflected in the parameters discussed in this report. 


\section{SUMMARY}

Because of the speculative nature of the design configuration, site criteria for a controlled thermonuclear power plant (CTPP) have not been developed yet. However, based on experience with fission powered plants, one can develop site criteria which are probable for such a machine. These criteria are discussed below relative to the Hanford Site:

- Land--Hanford has available more than 150 square miles of governmentouncd land that readily meets probable topographic, geologic, and seismic criteria. There is also available ample room for cooling ponds.' This huge section of land will probably meet any isolation criteria set. A large land requirement is generated by the possibilities of significant energy release or radioactiv: release during potential accidents.

- Poirer--Hanford has surplus electrical capacity already installed to meet the demands of the largest prototype--at the lowest rates in the U.S. The available power grid, because of its large hydrogenerating capacity, is also ideally suited for maintaining its integrity in the face of the large transient behavior of prototype oneration.

- Water--The Columbia River offers the largest supply of pure, cold water in the U. S.; there are excellent surplus reactor water plants available.

- Potential By-nroducts--there are potential by-product concepts which would be uniquely applicable at the Hanford site. These concepts include fusion/fission, plutonium breeding and fission product destruction.

- Unique Site Capabilities--Hanford has a variety of unique capabilities available for application to CTPP siting problems. These characteristics include safety considerations and exploitation of existing facilities. 
- Transportation--two major railroads have direct connections to the Hanford Project rail system; multi- 1000-ton barge service is also available. There is excellent highway access to the area.

- Manpower--a high level of scientific and technical personnel as well as construction and craft labor is aiready in residence.

- Services--complete support-type services, such as industrial shops, bus transportation, radiation protection, and plant security, are immediately available. There is available locally ample experience with large scale specialized construction.

- Cominunity--the area has an exceptionally high education level, equal to the outstanding areas of the U.S.

In total, the many tangible assets of the Hanford Project offer potential dollar savings in the development of a prototypic power plant. Shutdown of the large production reactors makes many millions of dollars worth of excellent support facilities and manpower readily available.

\section{INTRODUCTION TO THE HANFORD PROJECT}

The Hanford Project is a complex of production, research and development, and supporting facilities; it covers a 575 square mile area of southeastern Washington (Figure 2). For more than twenty-five years Hanford was the chief producer of plutonium in the United States and was operated by the General Electric Company as prime contractor. In January, 1964, when a decision was made to curtail production and shut down three of the nine plutonium production reactors by mid-1965, a planned segmentation of Hanford to different contractors was cegun. At present, Hanford contractors include Douglas United Nuclear as operator of the production facilities, Battelle-Northwest as operator of the 


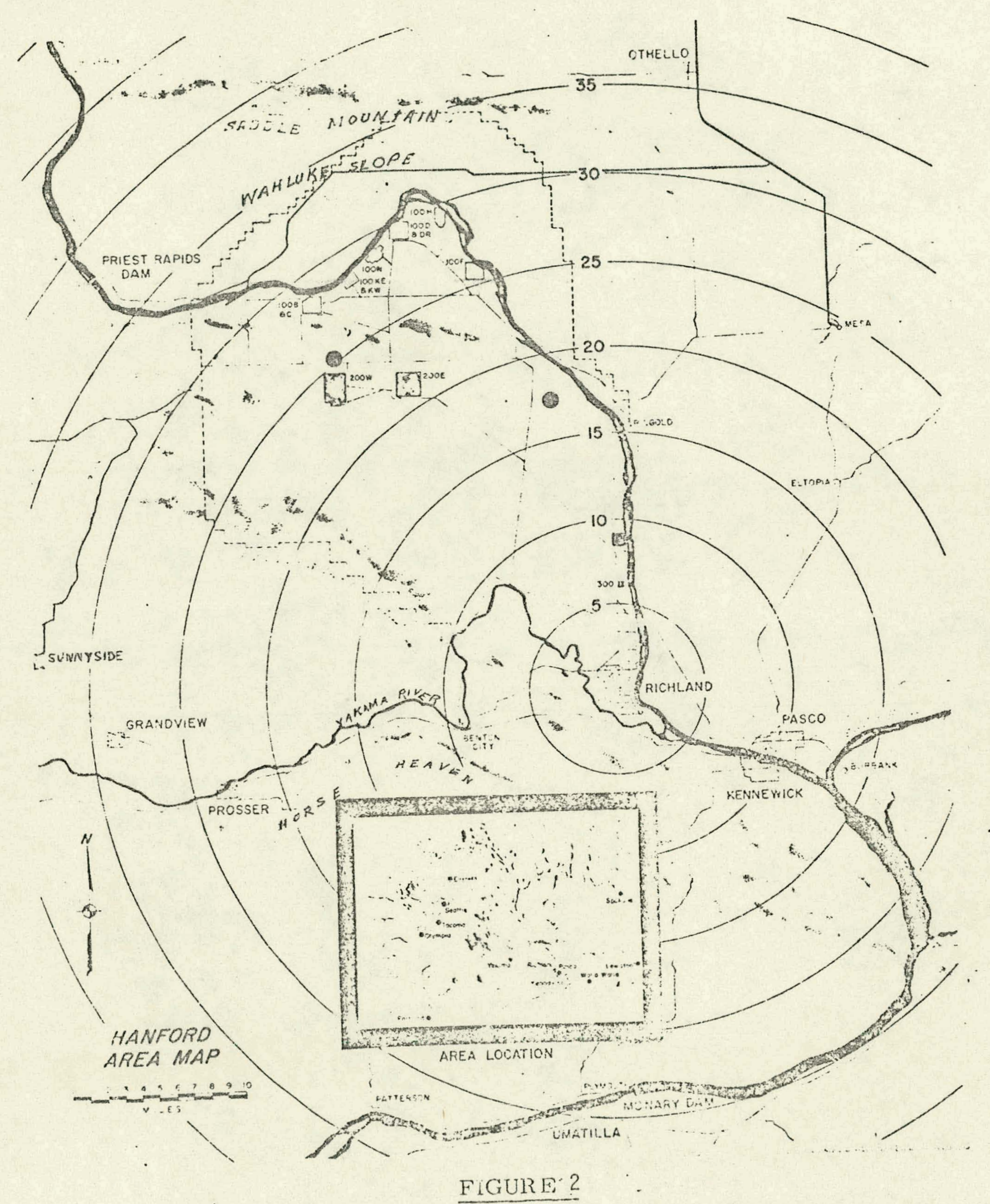

The Hanford Site 
R\&D laboratories, WADCO Corp. as contractor for LMFBR and related research, Atlantic Richfield as operator of chemical separation plants, J. A. Jones Co. providing construction services, Computer Science Corporation as contractor for data processing, and ITT providing general support services to the contractors. (1)

\section{SITE .QUALIFICATIONS}

Certain factors have been considered in developing the qualifications of Hanford as a potential site for a large Controlled Thermonuclear. Power Plant (CTPP). The primary factors considered were:

- Land

- Power

- Water

Secondary factors considered include:

- Transportation

- Manpower

- Services.

- Community

These factors are discussed in detajl below. Availability and Characteristics of Larld

Land Areas and Potential Sites

The Hanford Project with three typical site areas shaded is shown in Figure 3. In each of the two northern areas, a 10 square mile land area is available which is level to within thirty meters. "The shaded area to the south is approximately 130 square miles. Each of these shaded areas satisfy other land criteria discussed below. Therefore, there is more than sufficient land at the site for such a project. 


\section{Geological and Topographic Characteristics}

The geology of the Hanford Project is characterized by three rock formations. The Columbia River Basait series forms the bedrock of the region. The thickness of the basalt series is estimated at about 15,000 feet. The Ringold formation generally overlies basalt at a depth of about 500 feet. Gable Mountain

(Figure 3) forms an anticlinal basalt ridge. Other local basalt out-croppings are found in the center of the northwester': shaded area (Figure 3). Late Pleistocene to recent fluviatile and glacio fluviatile sediments overlie the irregularly eroded surface of the Ringold Formation. The foundation materials are unconsolidated, but compact, sandy gravels and gravelly sands. They can be excavated at low-cost. The subsurface conditions in all three shaded areas (Figure 3 ) are indicated by representative sections at the indicated locations where wells were drilled to obtain geological and hydrological data. Bearing strengths of the undisturbed gravels and sands are consistently in the range of 6.5 tons $/ \mathrm{ft}^{2}$. Greater loadings may be possible but in any case could be provided by spreading the footing or localized use of piling.

Seismic Stability

The need for very good ground stability at a CTPP site is most obvious. The Hanford region is seismirally a very stable area. This stability, which has been a significant safety and economic consideration in the continued location of large production reactors at the site, is most likely the result of the thickness of the basalt series. Tectonic stresses that develop appear to be relieved by basining and folding; hence, faults at the surface and at depth appear to be of minor significance. 'Interpretations of seismograph records have not indicated epicenters in the immediate Hanford area. Many earth tremors have been recorded by Hanford reactor instruments but in nearly all cases they have been correlated to known quakes throughout the world. 


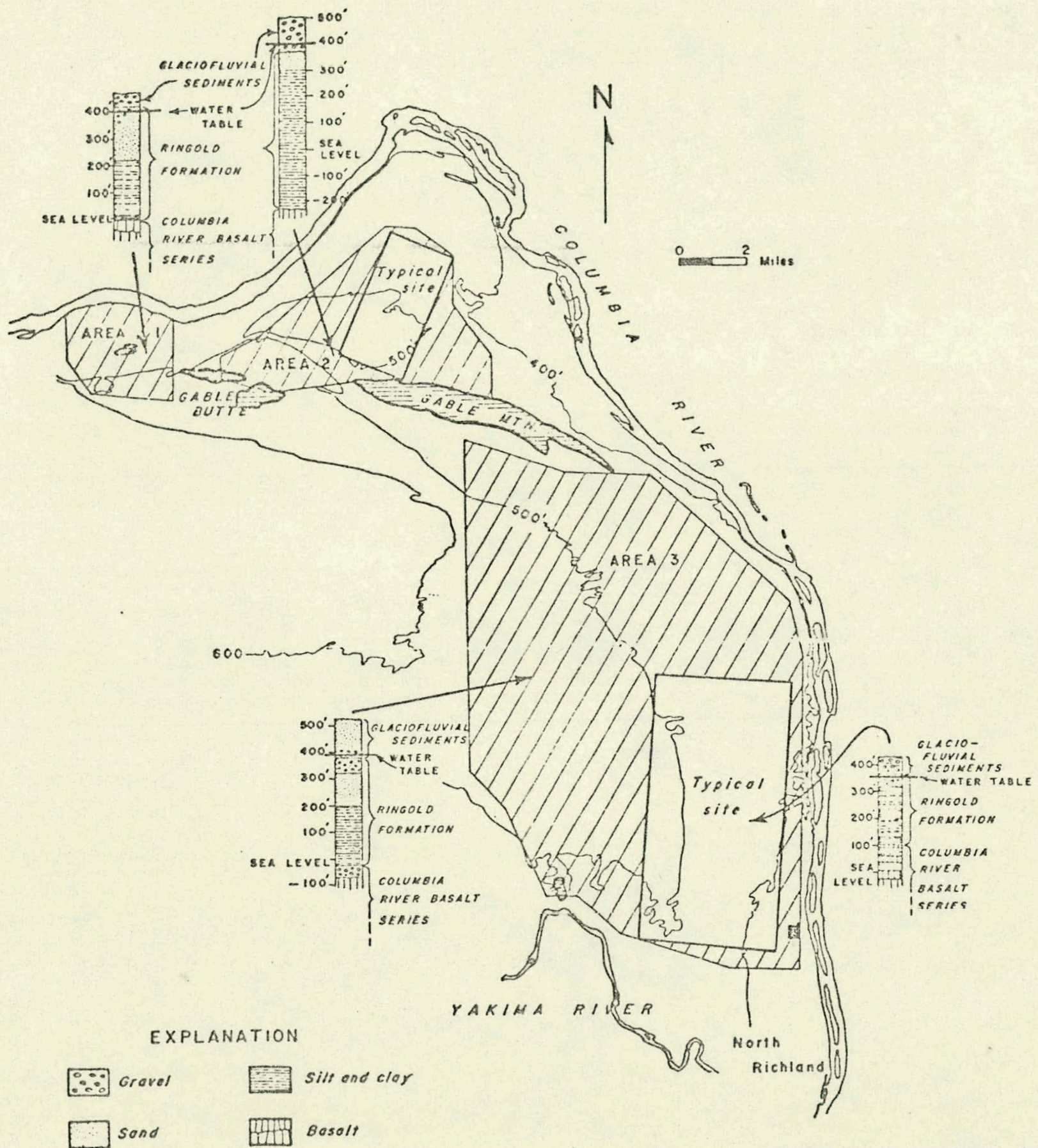

Figure 3

Hanford Project Showing Possible CTPP Sites 
The potential of damage to substructures exists, but appears to demand earthquakes originating locally and emitting waves that are amplified as they pass through the basin-fill sediments. Such amplifications, by resonance, can take place with waves of about 0.2 second period. Waves of that period are normally damped out in passage through sediments, and only the longer-period waves are propagated. Therefore, a local source is required. If buildings with similar period of vibration lie $i_{i}$ ine wave path, they could suffer damage from a low intensity earthquake of this description. This vibration period should be avoided in Hanford site construction. More details of seismic investigation of Hanford are given in Reference 2.

For comparison of the seismic stability of the Hanford region, the expected probability of earthquake damage is about the same as that at the National Reactor Testing Station, and both probabilities are quite low. For building code purposes, the entire area east of the Cascade Mountains in Washington is in Zone 2 of the Seismic Probability Map. (3). However, for construction of power plants, a horizontal acceleration of $0.3 \mathrm{~g}$ instead of $0.12 \mathrm{~g}$ as called for by Zone 2 should be used.

\section{Water Table}

Large construction items can require a stable water table at least 30 feet below the minimum ground level. This allows for construction of subbasements with adequate foundation and, in addition, gives the flexibility to use underground construction for shielding purposes. The shaded areas in Figure 3 , represent possible prototype sites which satisfy this criteria. Typical depths are shown in the indicated drillings. There has been discussions for many years of the addition of a dam (Ben-Franklin) on the Columbia River at a site a few miles north of Ricilland. Current plans make this unlikely. However, if it is built, the anticipated change in ground water table would mean only an insignificant part of the southernmost site would no 
longer meet this criteria. Further details of ground water table at Hanford can be found in Reference 4 .

\section{Electrical Power}

The electrical power requirements of a large prototypic fusion device can be discussed in two parts. First, there are general house load requirements whereby the prototype draws on the power grid for electricity to operate its systems during periods of testing and maintenance while the device itself is not operating. In addition, there are the transmission requirements of the prototype to be considered. These requirements include a system stable enough to withstand the potentially large transients resulting in the testing of the device and also the ability to transmit the large blocks of power to be generated at the site.

Prototype designs being considered in the literature are in the range of 5000 . Wve ${ }^{(5)}$ although the first prototype might be somewhat smaller. Typical values for a ratio of fusion power to injection power are of the order of 20. A 5000 me device would then require 250 ine for injection power. This number could be considerably larger if the injection efficiency were appreciably less than 100\%. In addition, one can estimate the power requirements of the conventional power plant to be of the order of $5 \%$ of the gross. This requirement would be 250 Mwe for a 500 Mve prototype. Therefore, the total requirements for such a prototype could be at least 500 Mve or larger.

The Pacific Northwest is unique in its ability to provide these large blocks of electrical pover at the lowest possible cost and at high reliability. The power at Hanford is purchased from the Bonneville Power Administration, whose interconnecting transmission system integrates with the Northwest power pool. Hanford is connected into the power pool through the Bonneyille Power Administration llidway switching Station located near the rorthwes: incundary of the Project. (Fịure 4) and the $N$ systell $500 \mathrm{kv}$ Tines. 
Three interconnected $230 \mathrm{kV}$ lines from Midway form the primary power network serving the plutonium production areas. Because of the shutdown of seven Hanford production reactors by mid-1969, essentially the full power-carrying capacity of two existing lines would be available for power. There are also three $500 \mathrm{kV}$ lines which have been installed to $\mathrm{H}$-Area (See Figure 4). Additional lines are. expected to be added with the construction of Hanford-2. A CTPP located in a northern site of the llanford Plant yould require essentially no construction cost for trans!nission lines. A CTPP siti: it the extreme southern end of the flant would require at most 15 to 20 miles of installed line. Cost of construction for $500 \mathrm{kV}$ lines would be of the order of $\$ 125,000 /$ mile which is quite low.

Electrical power distribution for the Hanford Project is administered by ITT, Federal Support Services. Partly because of the large load required at Hanford, electrical power costs are of the order of $2.4 \mathrm{mills} / \mathrm{kw}-\mathrm{hr}$. This rate is far below that available elsewhere in the U.S. (Table I). The electrical costs at other AEC sites as of 1965 are shown in Table I for comparison.

If the prototypes built are actually of the order of 5000 Mwe, the transient stability problems connected with the transmission system will be formidable. The Pacific llorthwest pover arid is perhaps unique in the U.S. in that a high percentage of its base pover generating capacity will be of the hydro-electric form for some time to come. The hydroelectric plant is recognized to have the quickest response to system transients. The Pacific llorthwest grid is thus admirably equipped to handle expected power transients developed by the prototypic nature of the device. 


\section{TABLE I}

\section{ELECTRICAL COSTS}

Site

San Francisco

Brookhaven

Argonne

Idaho Falls

Oak Ridge

Denver

Albuquerque

Hanford

* As of Jan. 1965.
Average Cost ${ }^{*}$

Mills/kwh

9.92

11.05

9.85

6.52

4.13

10.08

12.0

2.41 


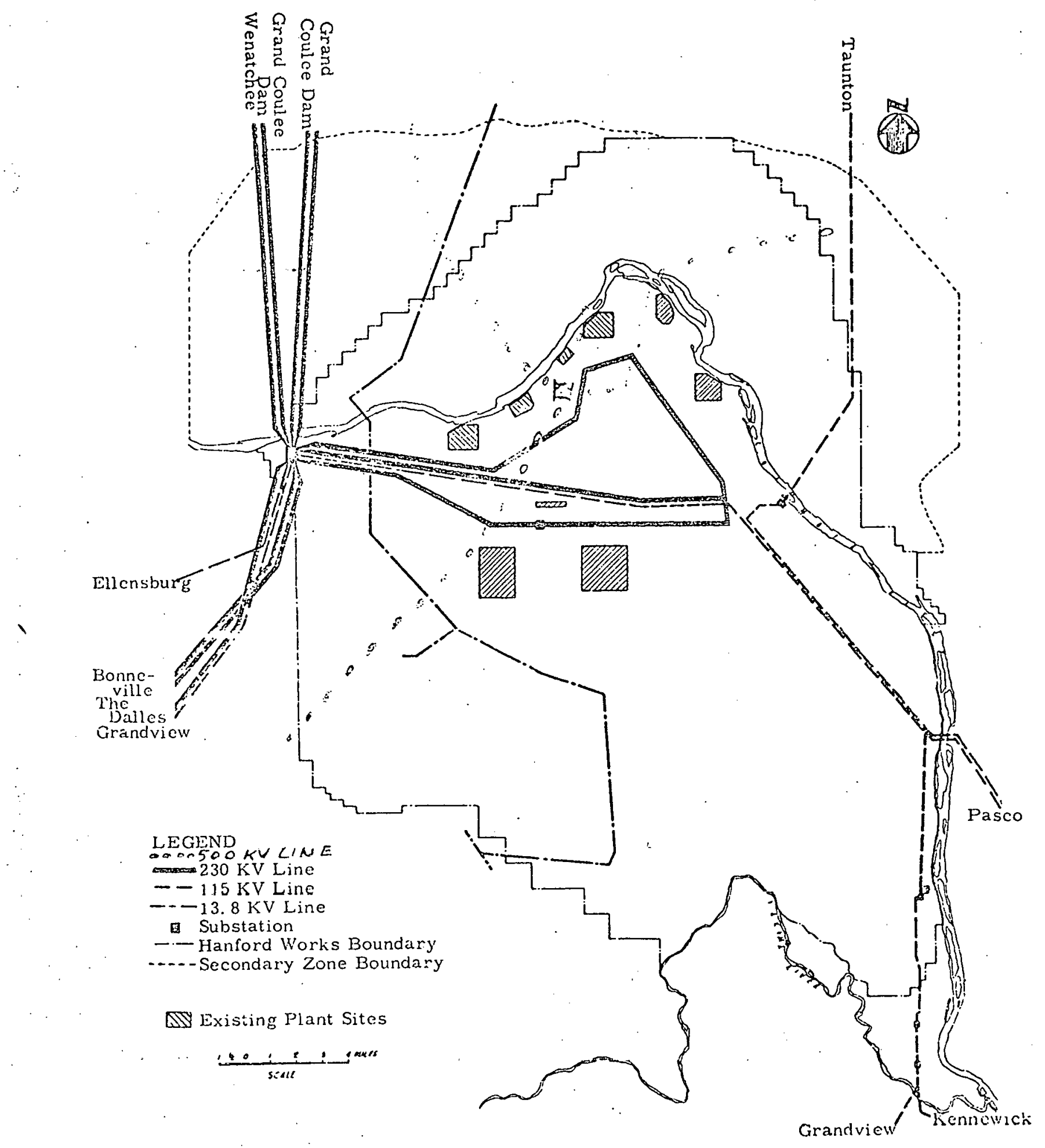

FIGUies a

Existing Electrical Power. 
Finally, prototypes of this size require transmission systems capable of distributing and utilizing large blocks of power. With the advent of the California intertie, the Pacific Northwest transmission system will be more than adequate for this job.

\section{Coolant Hater}

One consideration which led to the original location of the Hanford Project was the use of Columbia River water for reactor coolant. Columbia River water is relatively pure; it has the lowest silt rate of any major river in the U.S. The flow rate is high, ranging from about 35,000 to $430,000 \mathrm{ft}^{3} / \mathrm{sec}$ and averaging about $120,000 \mathrm{ft}^{3} / \mathrm{sec}$. The water stays fairly cold throughout the year with maximums less than $70 \mathrm{~F}$ in Julv and minimums of about $39 \mathrm{~F}$ in January.

The above facts indicate that a more than adequate heat sink exists for a prototypic CTPP at the Hanford site. Cooling ponds, if required by changing environmental considerations, can be readily located in the area due to available land. Additionally, a potential agro-complex based on irrigation by waste heat water is possible in areas close to the site. ${ }^{(6)}$

POTENTIAL BY-PRODUCTS

One of the characteristics of the proposed CTPP is that it is a neutronrich device. That is, it can have a potential breeding ratio of 1.3 or higher for the production of tritium. However, one would probably want to operate with a brecding ratio slightly in excess of 1 shortly after initial startun. Excess tritium would have limited usefulness and could constitute a hazards problein. 
There are potential applications for this source of excess neutrons which would be particularly appropriate for the Hanford site. One of these potential applications would be as a fission product burner. There are stored at Hanford significant quantities of fission products which could be used to form the basis of an experimental program to develop means of burning stored fission products by neutron activation. If the process were developed sufficiently, there are significant quantities of fission products available on site for an cxtended nrogram. It can be shoun that only a fusion device will have sufficiert neutron flux to even consider such an approach. This could prove more economical to the AEC than the current storage program. An associated potential byproduct could be utilization of local R\&D expertise in all phases associated with the project.

Another application could be in the production of cheaper plutonium. The $14 \mathrm{MeV}$ neutrons, with a flux of the order of $10^{15}$, generated by the device could be, easily moderated to resonance energy neutrons with a corresponding high production of high grade plutonium. With the advent of the nuclear park concept at Hanford, there will be more than sufficient reprocessing capability on site to handle this plutonium. The combination would result in an extremely economical source of plutonium for fission reactors when coupled with other capabilities uniquely available at the Hanford site. It appears that, in principle, a CTPP could, in addition to carrying out its role as a power source, produce enough plutonium. to service one or more fission plants.

\section{IliIIQUE SITE CAPABILITIES}

Unique lianford site capabilities can be discussed relative to two areas. These areas are: 
- Safety considerations.

- Exploitation of existing facilities.

These considerations are discussed below in a summary manner. Additional information on these points can be made available.

The primary safety consideration associated with the operation of a CTPP probably would be accidental release of significant inventories (10-200 kg) of tritium to the environment. The Hanford site has demonstrated proper and proven subsoil characteristics for dealing with inadvertent tritium release. As a result of the operation at Hanford over several years of fuel reprocessing facilities, there is a significant tritium deposit in the soil beneath the reprocessing plants on the Hanford site. This deposit has been extensively studied and found to have stabilized after 8-10 years from initiation. This stabilization in the growth of the deposit reflects the half-life of the isotope and also the soil and ground water characteristics of the site. The deposit stabilized long before it reached river water sources. It has, therefore, !oon adenuately contained within the site. This capability should be a significant coisideration or CTPP siting. The other safety consideration, liquid metal energy release with possible radioactive contamination is also compatible with the Hanford site.

The Hanford site is sufficiently isolated from large populated groups so as to make the operation of a CTPP at that site an extremely. low risk venture for the general public almost independent of the particular hazard under consideration.

A substantial number of facilities at Hanford are now surplus due to the shutdown of seven production reactors. These facilities include large buildings that could be used for assembly and storage, steam-generating plants, water treatment plants, and others. For further information on this subject the AC-C.E Study Group has prepared a complete listing of available facilitios. (7) 
TRANSPORTATION

\section{Freight}

The CTPP construction would probably require the shipment of large equipment items weighing many tons. Again, Hanford has much to offer. At present two barge lines provide daily service from Pacific Coast ports to the Port of Pasco, 15 miles south of Area 3 (Figure 3). Loads of 1000 tons or greater can be barged into this area. With the John Day Dam on the Columbia River, slack water with a minimum depth of 15 feet exists between Hanford and the Pacific Coast and results in an extensive barge capacity.

Ground freight transportation is also good, both to the Tri-city area and within the Hanford Project. Hanford has 270 miles of primary roads, 175 miles of secondary gravel roads, and 225 miles of gravel and unimproved roads. It also has its own rail system with 150 miles of track. There are four major highways serving the Tri-City area; a new highway has been completed to provide better access to Seattle; and a new interstate highway from Seattle will go through, or near, the Tri-City area. The Tri-Cities is a major rail center. It is served by the Union Pacific and Burlington Northern railroads.

\section{Personnel}

It may be desirable for a project the size of a CTPP protot.ype to be near a major airline terminal. However, the distance from a metropolitan terminal to final destination may have little relation to the travel time required. Most remote potential power plant sites are 1 or 1-1/2 hours away from metropolitan terminals. Hanford is no exception. Major jet terminals for the Tri-City area are Portland, Oregon; Seattle, Hashington; and less frequently Spokane, Washington. Mir West Airlines provides jet connections from Pasco to these terminals in about an hour's fiying time. It is possible that conecting serviccs vould be 
improved if the demand associated with a CTPP were sufficiently large. In any case, it is usually possible to reach any destination within the United States within one days travel.

SUPPORTING SERVICES

Hanford is an industrial site with some 10,000 employees. Included in the complex are the J. A. Jones $C_{0}$., which provides plant construction services and manages a large machine shop; the Battelle-Northwest and HADCO laboratories with many assorted fabrication and development shops; and other shop services in the Chemical Processing and Reactor Plants. In the segmentation of Hanford the supporting services were assigned to ITT Federal Support Services as a contractor. These support services include:

- Fire Protection

- Security Guards

- Contaminated Laundry Facilities

- Bus and Rail Transportation

- Electrical Power Distribution

- Plant-Wide Telephone System

- Printing, Central Warchousing, etc.

The United States Testing Co. provides radiation film badge processing and other services. Electronic Data Processing service is provided to area customers by Computer sciences Corporation. Extensive radioactive waste disposal services are available at Hanford. A large pipe-fabrication plant is operated in the Tri-cities. Further information on these and other industrial activities in the Tri-City area can be obtained from the Tri-City ituclear Industrial Council. 


\section{The Tri-City Community}

Many of the readers of this report are undoubtedly without knowledge of the characteristics of the Hanford area. For those, we have summarized a few of the attributes which we feel would be of most interest.

\section{Population}

- Adjacent to the Hanford Plant are the Tri-Cities of Richland, Kennewick, and Pasco, Hashington. Each community is similar in population with a total of about 100,000. Many llanford employees live in Kennewick and Pasco which are 8 to 10 miles furcher away from the Project than Richland. When all housing in Richland was government-owned many people moved to these communities to obtain private housing. Others continue to locate there for a variety of reasons.

\section{Education}

- The technical work force at the Hanford Plant has resulted in an educational level of the population of the Tri-Cities which is abnormal for a community of this size. There are some 3500 college graduates in the area representing over 2500 technical degrees. For comparison, the per capita ratin of professional people to total work force in the TriCities is approximately equal to that of the Boston or San Francisco areas.

- The Tri-city schools are among the top in a state which consistently ranks among the top three in the nation by the standards of the liational Educational Association. The State of Hashington ranks ninth in expenditures per pupil. Each city has six or seven elementary schools, two junior high schools, and one or two high schools. There are Catholic parochial schools 
for Grades'1 through 8 in each city, a Lutheran parochial school in Kennewick, and Seventí bay Adveritist parochial school in Pasco. Libraries, cafeterias, gymnasiums, spacious outdoor playgrounds, and athletic facilities are to be found. in nearly all schools. The excellence of the public school system in the TriCities has always been an attraction to the scientists who have located at Hanford. Columbia Basin Junior College is fully accredited for freshman and sophomore work with both the University of Washington and Washington State University. The college accommodates more than 3000 students with day aind night classes. Adult evening education classes offering extensive academic, vocational, and business training are conducted by the school systems in Pasco and Richland.

The need for continued association and participation in university research and course vork is obvious both for the professional scientist and the scientistin-training. The need has been recognized at Hanford. The AEC at Hanford has always sponsored graduate course work in arts and sciences. Some laboratory work has been provided but this has been limited. This graduate program is now administered by the University of Washington as the Joint Center for Graduate Study at Ficilland. Washington State University and Oregon State University a) so share in administrating this activity. The lectures for the center are provided almost exclusively from the professional siaff at Hanford which includes some 140 Ph.o.s. In addition, regular lectures on topics of scientific interest are held in the Tri-cities area under sponscriship of the ARCHO company. These lectures are given by experts from throughout the world. As an indication of 
the effectiveness of this small graduate program, an incomplete survey indicates that some 18 former students and Hanford researchers in physics alone have subsequently received Ph.D degrees at universities throughout the country.

- Excellent library systenis are operated in each city. These libraries are stocked and operated in keeping with the high standards of the area schools. Movies, recordings, and art works are loaned. Usage of the libraries reflects the high level of intellectual interests of area residents. For examnle, the use rate in Richland is three times the national average. The Hanford Project Library, administered by Battelle-llorthwest, is one of the best-equipped technical libraries in the U.S.

Living, Recreation, Climate

- People living in the Tri-City area may choose between urban or rural living and may rent, buy, or build homes of their choice. Many residental districts with excellent new homes exist throughout the area.

- Each city has a community concert series with visiting artists. The area supports a symphony orchestra of community artists. There is a "little. theatre" group which owns its own theatre, a number of choral groups, and an amateur light opera company.

- Mountain ranges on all sides of the Columbia Basin form a protective weather barrier which results in a mild, very dry climate with moderate winters and warm summers. The region is ideally suited for outdoor living more than six months of the year and visibility is seldom less than 10 miles. CONCLUSIONS

Several conclusions can be made relative to siting a Controlled Thermonuclear Power Plant at Hanford and indeed, conclusions can be made as to the timing of 
sucl a nced. These conclusions, in surmary form, are given below:

- A site should be selected for a CTPP probably before 1980.

- If the usual constraints on large prototypic power sources hold true for the CTPP, the Hanford site qualifications in terms of land, power, water, transportation and so forth are excellent.

- Ns far as the safety requirements can be defined, the Hanford site has a demonstrated capiability for coping with theni.

- The Hanford site has some unique features capable of enhancing such an undertaking which cannot be readily found at other sites. These include exploitation of existing facilities.

- The llanford site has a large cadre of technologically trained personnel well versed in the problems of putting physical theory into engineering practice. 


\section{REFERENCES}

1. B. R. Leonard, Jr., Special Report lianford As a Site for Large Accelerators, BNWL-11, January 1965.

2. F. Newmann. Seismological Investigations of the llanford Area, HW-63832, Hovember 2, 1959.

3. Pacific Coast Building Officials Conference, Uniform Building Code, 1959 Edition.

4. W. H. Bierschenk. Aquifer Characteristics and Ground-Water Movement at Hanford, HW-60601, June 9, 1959.

5. A. P. Fraas and 11. Postma, "Prelininary Appraisal of the Hazards Problems of a D-T Fusion Power Plant," ORNL-TM-2822, Oak Ridge National Laboratory (Apri1 1970).

6. Private Conmunication, 1. R. Young, Battelle-Northwest.

7. P. G. llolsted and F. W. Albaugh, Catalog of Hanford Buildings and Facilities, 100 Areas, 200 Areas, 300 Areas (3 documents), Available from Richland Operations Office, USAEC, Richland, Washington, (April 1964). 
No. of

Copies

Atlantic Richfield Hanford Company

7
P. P. Corlew
B. B. Field
R. E. Isaacson
E. McIntyre
L. M. Richards
A. E. Snith
R. E. Tomlinson

S

Douglas United Nuclear

C. D. Harringtor.

R. T. Jessen

C. H. Kuhtmann

W. K. MacCready

B. K. Robinson

K. - . Robinson

0 . C. Schroeder

J. L. Schwennesen

i. K. Woods

38

Battel Te-Northwest

N. E. Carter

G. Dau

1). R. Dellalas

F. G. Dawson

D. E. Deonigi

K. Drumbel1er

L. Finch

H. L. Henry

A. B. Jolunson

G. Kulcinski

B. R. Leonard

R. C. Liikala

C. M. Lindermeier

R. P. Marshall

R. Paul

L. C. Schmid

R. I. Smith

W. C. Wolkenhauer (1.5)

J. R. Young (6)

Technical Files (2)

10

U.S. Atomic Energy Conmission
O. J. Elgere
H. E. Parker
R. L. Plum
J. E. McDonald (6)
ii. R. Schneller 